\title{
PERAN DANA PIHAK KETIGA DALAM MEMEDIASI PENGARUH NET INTEREST MARGIN TERHADAP PERTUMBUHAN KREDIT PADA PERBANKAN YANG GO PUBLIC DI BURSA EFEK INDONESIA
}

\author{
Pristin Prima Sari \\ Ardian Prima Putra \\ Universitas Sarjanawiyata Tamansiswa \\ Universitas Veteran Bangun Nusantara Sukoharjo \\ Pristin.primas@gmail.com \\ ardian.putura@gmail.com
}

\begin{abstract}
s
The study found empirical proof the role of third party funds (DPK) mediate the influence of net interest margin (NIM) on bank credit growth listed in Indonesia Stock Exchange on 20152018. The study uses data from the bank's annual financial statements. The Study covers 22 commercial banks resulting in 88 bank-year observations. Research using Smartpls 3.0 statistical tools to process data and path analysis to compute data. The results obtained are third party funds (DPK) that can positively mediate the influence of net interest margin (NIM) on credit growth. The greater DPK create the profitability of bank interest rates increases bank credit growth. Partially Net interest margin (NIM) and third party funds (DPK) can increase bank credit growth. Net interest margin (NIM) also can increase the amount of third party funds (DPK). This study is useful for bank management to make decisions on determining bank margins, obtaining third party funds (DPK) and credit, for the government for study and mapping materials related to bank lending and the amount of bank interest rates, for further research is for reference material related to factors affecting lending.
\end{abstract}

Keywords : Net Interest Margin, Third Party Fund, Credit Growth, IDX

\section{PENDAHULUAN}

Pertumbuhan kredit merupakan salah satu ukuran kinerja bank. Bank yang berkinerja dengan baik adalah bank yang memiliki pertumbuhan kredit. Kredit bank merupakan sumber penghasilan bank yang utama selain layanan jasa bank. Fungsi bank yang paling penting adalah menghimpun dana dan menyalurkan kredit kepada masyarakat. Fungsi penyaluran kredit bank kepada masyarakat adalah memberikan suntikan dana untuk pengembangan usaha kecil, memberikan kredit modal kerja untuk pemberdayaan masyarakat, memberikan kredit investasi seperti perumahan, pendidikan dan sebagainya. Kredit bank dapat mengurangi kesenjangan sosial ekonomi masyarakat, menggerakkan perekonomian masyarakat, menggeliatkan pertumbuhan bisnis.

Kredit Bank Umum di Indonesia mengalami pertumbuhan selama tahun 2016-Bulan Juli 2019. Tabel kredit Bank Umum ada pada tabel 1.

Pada tabel tersebut menunjukkan bahwa pertumbuhan kredit modal kerja Bank 
Tabel 1

Kredit Modal Kerja Bank Umum Di Indonesia 2016-Juli 2019

(Rp Miliar)

\begin{tabular}{ccrrrrr}
\hline Tahun & Persero & $\%$ & $\begin{array}{c}\text { Bank Swasta } \\
\text { Nasional }\end{array}$ & $\%$ & $\begin{array}{c}\text { Bank Asing \& } \\
\text { Campuran }\end{array}$ & $\%$ \\
\hline 2016 & 696,007 & - & 766,304 & - & 148,570 & - \\
2017 & 764,485 & 0,098 & 847,481 & 0,105 & 125,828 & $-0,15$ \\
2018 & 854,392 & 0,1176 & 924,733 & 0,091 & 163,045 & 0,295 \\
Jul-19 & 862,884 & 0,00993 & 960,560 & 0,0387 & 148,760 & $-0,0876$ \\
\hline
\end{tabular}

Sumber : www.bi.go.id

Persero (Bank Pemerintah), Bank Swasta Nasional dan Bank Asing Dan Campuran di Indonesia tahun 2016- Juli 2019. Bank Persero dan Bank Swasta Nasional mengalami pertumbuhan positif pada kredit modal kerja tahun 2017 sampai Juli 2019. Bank Asing dan Campuran mengalami pertumbuhan negatif pada kredit modal kerja pada tahun 2017 dan pertumbuhan positif pada tahun 2018.

Penelitian terdahulu menemukan bukti empiris bahwa suku bunga dan faktor makro berpengaruh terhadap penyaluran kredit BPR di Yogyakarta (Rinofah, 2018), Skim bunga kredit dan profitabilitas berpengaruh terhadap kredit bank (Sri Hermuningsih, 2011). Margin bank dapat meningkatkan pertumbuhan kredit (Romli \& Alie, 2017). Dana pihak ketiga (DPK) dan nim berpengaruh terhadap penyaluran kredit (Pratiwi \& Hindasah, 2014). Risiko suku bunga dapat mempengaruhi besarnya dana pihak ketiga bank dan penyaluran kredit kepada masyarakat (Bank of Indonesia, 2017). Dana pihak ketiga mempengaruhi jumlah pembiayaan bank syariah (Ratu Mashita Gumilarty \& Indriani, 2017).

Net Interest Margin (Aini Nihayati, Sugeng Wahyudi, 2014)adalah profitabilitas bank dari pengelolaan aset dan fungsi intermediasinya yang berupa bunga pinjaman dan bunga simpanan. NIM di Indonesia tergolong tinggi yang disebabkan oleh pendanaan usaha mikro, kecil dan menengah dan kredit perumahan (Trinugroho, Agusman, \& Tarazi, 2014). Meskipun NIM bank tinggi maka Bank tetap dapat menyalurkan kredit bank sehingga NIM yang besar maka penyaluran kredit bank juga besar. Cara menentukan NIM adalah selisih suku bunga kredit terhadap suku bunga simpanan dibagi total aset. Suku bunga bank menentukan besarnya dana yang akan dibayarkan nasabah kepada bank atas sejumlah dana yang dipinjam. Semakin besar penetapan suku bunga bank umum maka margin bank juga akan besar. Semakin besar margin bank maka pendapatan bank akan semakin besar. Margin bank menentukan jumlah penyaluran kredit. Bank yang mendapat penghasilan besar dari margin bank maka akan semakin besar menyalurkan kredit. Bank yang menetapkan suku bunga semakin besar maka menurunkan penyaluran kredit bank.

Net Interest Margin (NIM) juga merupakan ukuran kompetisi bank (Trinugroho, Risfandy, \& Ariefianto, 2018). Besarnya NIM yang semakin kompetitif maka akan menarik masyarakat untuk mengambil kredit di bank. Dengan demikian, besarnya NIM dapat menentukan besarnya jumlah penyaluran kredit bank.

NIM berpengaruh terhadap dana pihak ketiga (DPK). Dana pihak ketiga (Pratiwi \& Hindasah, 2014) terdiri dari tabungan, deposito, dan giro. Margin bunga bank semakin besar maka dana pihak ketiga 
akan meningkat. Margin bunga bank yang rendah bearti bank menurunkan tingkat keuntungannya dengan memperbesar pemberian bunga simpanan sehingga mendorong dana pihak ketiga meningkat.

Dana Pihak ketiga (DPK) merupakan dana simpanan dari masyarakat. Bank menetapkan suku bunga simpanan atas dana pihak ketiga (DPK). Semakin besar suku bunga simpanan maka dana pihak ketiga (DPK) akan meningkat. Dana pihak ketiga (DPK) digunakan bank untuk menyalurkan kredit kepada masyarakat. Semakin besar DPK maka pertumbuhan kredit bank akan meningkat. Semakin besar DPK maka memudahkan bank dalam menyalurkan kredit. Semakin besar DPK maka mempengaruhi besarnya faktor suku bunga berpengaruh terhadap pertumbuhan kredit bank. Dengan demikian, DPK dapat memediasi pengaruh net interest margin (NIM) terhadap pertumbuhan kredit bank.

Tujuan penelitian adalah Untuk menguji secara empiris pengaruh positif margin bank (NIM) terhadap penyaluran kredit, peran mediasi Dana Pihak Ketiga (DPK) terhadap pengaruh NIM dan pertumbuhan kredit bank dan pengaruh NIM terhadap pertumbuhan DPK.

Manfaat penelitian adalah Bagi Manajemen Bank, penelitian ini bermanfaat untuk mengetahui faktor yang dapat mempengaruhi pertumbuhan kredit bank. Sehingga manajemen bank dapat membuat kebijakan untuk kinerja pertumbuhan kredit bank. Bagi Pemerintah, Pemerintah dapat membuat kebijakan suku bunga acuan untuk meningkatkan kinerja kredit bank. Penelitian ini juga menjadi pemetaan kinerja kredit bank di Indonesia. Dengan demikian, program pemerintah berkaitan dengan pemberdayaan masyarakat dapat berjalan lancar. Bagi Penelitian Selanjutnya, Penelitian ini menjadi bahan acuan teoritis terkait dengan penyaluran kredit bank dan faktor yang mempengaruhinya. Sehingga literatur terkait dengan kredit bank dapat bertambah.
Keterbaruan penelitian adalah adanya peran mediasi dari dana pihak ketiga (DPK) yang mempengaruhi besarnya margin bank (NIM) terhadap pertumbuhan kredit.

Penelitian tentang pertumbuhan kredit masih sedikit dilakukan oleh para peneliti sehinggapentinguntukmengetahuibesarnya pertumbuhan kredit bank dan faktor yang mempengaruhi pertumbuhan kredit. Faktor dana pihak ketiga (DPK) dan net interest margin bank masih jarang digunakan oleh para peneliti sehingga penelitian ini dapat menambah literatur tentang faktor yang mempengaruhi pertumbuhan kredit bank.

\section{TINJAUAN TEORITIS DAN \\ PENGEMBANGAN HIPOTESIS}

\section{Kredit Bank}

Kredit Bank terdiri dari kredit investasi, kredit modal kerja dan kredit konsumsi. Penyaluran kredit bank dipengaruhi oleh beberapa faktor antara lain dana pihak ketiga (Pratiwi \& Hindasah, 2014) dan net interest margin (Risal Rinofah, Ayu Laksita Widaresti, 2018). Semakin besar dana pihak ketiga (DPK) dan NIM yang dimiliki bank maka kredit bank akan meningkat.

\section{Margin Bank}

Margin bank (Trinugroho et al., 2014) adalah selisih bunga kredit dan bunga simpanan. Net Interest Margin (NIM) disebut juga biaya intermediasi. Semakin besar NIM maka bank akan mendapatkan keuntungan yang lebih besar. Besarnya NIM dapat meningkatkan tingkat penyaluran kredit.

\section{Dana Pihak Ketiga (DPK)}

Dana pihak ketiga (Pratiwi \& Hindasah, 2014) merupakan dana yang dihimpun dari masyarakat berupa tabungan, simpanan berjangka dan giro. Bank memberikan bunga simpanan kepada masyarakat atas dana yang disimpan pada bank. Dana Pihak Ketiga (DPK) adalah sumber dana bagi bank untuk menyalurkan kredit. Semakin besar jumlah DPK maka bank semakin mudah untuk menyalurkan kredit. 


\section{Pengaruh NIM terhadap Pertumbuhan} Kredit

Net interest margin (NIM) dapat menentukan besarnya bank menyalurkan kredit (Rinofah, 2018). NIM juga memiliki dampak terhadap transaksi bank khususnya kredit (Marinkovic \& Radovic, 2010). Semakin besar NIM maka pendapatan bank semakin meningkat sehingga bank memiliki ketersediaan dana yang cukup untuk menyalurkan kredit. NIM Bank di Indonesia yang cenderung tinggi tetap dapat menjaga pertumbuhan kredit bank. Hal ini dikarenakan sebagian besar kredit bank berasal dari kredit UMKM dan kredit properti (Trinugroho et al., 2014).

Berdasarkan teori diatas maka hipotesis penelitian adalah sebagai berikut:

$\mathrm{H} 1$ : Net Interest Margin dapat meningkatkan pertumbuhan kredit bank.

$\mathrm{H} 2$ : Net Interest Margin dapat berpengaruh positif terhadap Dana pihak Ketiga (DPK).

\section{Peran Dana Pihak Ketiga (DPK) Dalam Memediasi Pengaruh NIM Terhadap Pertumbuhan Kredit}

Dana Pihak ketiga (DPK) dapat meningkatkan ketersediaan dana untuk menyalurkan kreditbankkepada masyarakat. Jumlah DPK dapat mempengaruhi kredit bank (Pratiwi \& Hindasah, 2014). Dengan demikian, DPK dapat mempengaruhi besarnya NIM terhadap pertumbuhan kredit bank.

Berdasarkan teori diatas maka dapat dibuat hipotesis penelitian adalah sebagai berikut :

H3: DPK dapat meningkatkan pertumbuhan kredit

H4 : DPK dapat memediasi pengaruh NIM terhadap Pertumbuhan kredit Bank.

\section{Metodologi Penelitian}

Desain penelitian menggunakan penelitian kuantitatif karena data berupa angka dari laporan keuangan bank. Sampel

\section{Kerangka Pemikiran}

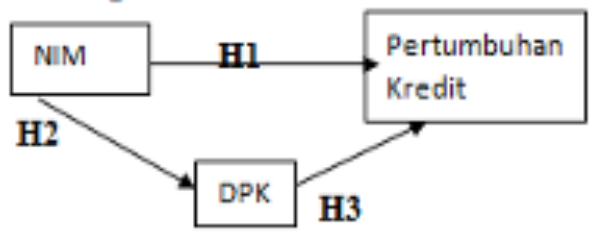

Gb1. Kerangka Berpikir

penelitian adalah bank yang terdaftar di Bursa Efek Indonesia tahun 2015 - 2018. Teknik pengambilan sampel (Sampling Technique) menggunakan metode purposif sampling. Metode purposif sampling adalah metode pengambilan sampel dengan tujuan tertentu. Kriteria pengambilan sampel adalah bank umum di Bursa Efek Indonesia yang menerbitkan laporan keuangan secara lengkap tahun 2015-2018.

\section{Definisi Operasional Variabel Variabel Dependen}

Pertumbuhan Kredit adalah peningkatan jumlah kredit yang diberikan oleh bank kepada nasabah dari tahun ke tahun. Pertumbuhan kredit diukur dengan skala desimal. Pertumbuhan kredit dihitung dengan selisih angka penyaluran kredit tahun sekarang dengan tahun lalu dibandingkan angka tahun lalu.

Pertumbuhan kredit $=\underline{\text { Kredit } \mathrm{t}-\text { Kredit } \mathrm{t}-1}$

Kredit $\mathrm{t}-1$

\section{Variabel Independen}

Net Interest Margin (NIM)

Net Interest Margin (NIM) adalah selisih bunga kredit dan bunga simpanan. NIM diukur dengan laba bunga / total aset produktif (Trinugroho et al., 2014).

$$
\mathrm{NIM}=\frac{\text { LabaBunga }}{\text { Total AsetProduktif }}
$$

\section{Variabel Intervening Dana Pihak Ketiga (DPK)}

Dana Pihak Ketiga (DPK) adalah dana yang terdiri dari giro, simpanan berjangka dan tabungan yang berasal dari masyarakat (Pratiwi \& Hindasah, 2014). Rumus DPK 
adalah log natural (Ln) jumlah giro + simpanan berjangka + tabungan.

\section{Teknik Analisis}

Pengelolaan data dalam penelitian ini akan diolah menggunakan program SmartPLS 3.0. teknik analisis menggunakan Path Analysis. Path Analysis adalah analisis jalur antar variabel penelitian dan merupakan pengembangan analisis regresi. Persamaan regresi adalah sebagai berikut:

$$
\begin{aligned}
& Y_{1 \text { kredit }}=\alpha+\beta_{1} \mathrm{NIM}+\mathrm{e} \\
& Y_{2 \text { DPK }}=\alpha+\beta_{1} \mathrm{NIM}+\mathrm{e} \\
& Y_{3 \text { kredit }}=\alpha+\beta_{1} D P K+e \\
& Y_{4 \text { redit }}=\alpha+\beta_{1} \mathrm{NIM}+\beta_{2} D P K+e
\end{aligned}
$$

\section{HASIL DAN PEMBAHASAN}

$$
\begin{aligned}
\text { Hasil Persamaan regresi: } & \\
Y_{1 \text { kredit }} & =0,197 \mathrm{NIM}+\mathrm{e} \\
Y_{2 \mathrm{DPK}} & =0,32 \mathrm{NIM}+\mathrm{e} . \\
Y_{3 \text { kredit }} & =0,195 \mathrm{DPK}+\mathrm{e}
\end{aligned}
$$

Tabel 3 menjelaskan pengaruh langsung variabel independen ke dependen. Hasil menunjukkan bahwa variabel DPK secara signifikan positif mempengaruhi pertumbuhan kredit (nilai signifikansi 0,044 dan koefisien 0,195). Variabel NIM secara signifikan positif mempengaruhi DPK (nilai signifikansi 0,000 dan koefisien 0,320). Variabel NIM berpengaruh signifikan positif terhadap pertumbuhan kredit (nilai signifikansi 0,043 dan koefisien 0,197). Hasil penelitian sama dengan hipotesis

Tabel 2

Statistik Deskriptif Tahun 2015-2018

\begin{tabular}{lllll}
\hline Variabel & Mean & Min & Max & $\begin{array}{l}\text { Standar } \\
\text { Deviasi }\end{array}$ \\
\hline NIM & 5,367 & 1,22 & 12 & 1,28 \\
DPK & 11,024 & 7,794 & 13,758 & $-0,118$ \\
Pertumbuhan Kredit & 0,059 & $-0,504$ & 0,377 & $-1,275$ \\
N & 88 & - & & -- \\
\hline
\end{tabular}

Sumber : data diolah, 2019

Tabel 2 menunjukkan bahwa besarnya sampel sebanyak 22 bank umum dan 88 data observasi laporan keuangan tahunan Bank di Bursa Efek Indonesia tahun 20152018. Besar rata-rata net interest margin (NIM) bank umum adalah 5,3\%, Dana pihak ketiga (DPK) sebesar 11 dan pertumbuhan kredit sebesar $5,9 \%$. dan penelitian terdahulu sehingga ketiga hipotesis diterima. DPK dan NIM dapat berpengaruh terhadap penyaluran kredit (Pratiwi \& Hindasah, 2014). Jumlah DPK yang semakin meningkat maka dapat meningkatkan jumlah pertumbuhan kredit bank. Jumlah NIM yang semakin meningkat maka dapat mendorong pertumbuhan kredit bank (Romli \& Alie, 2017).

Tabel 3

Uji Hipotesis Variabel

\begin{tabular}{ccccccc}
\hline Hipotesis & Variabel & $\begin{array}{c}\text { Original } \\
\text { Sample }\end{array}$ & $\begin{array}{c}\text { Standar } \\
\text { Deviasi }\end{array}$ & P Value & T Statistic & Ket \\
\hline Hipotesis 1 & NIM -> Kredit & 0,197 & 0,097 & $0,043^{* *}$ & 2,03 & Diterima \\
Hipotesis 2 & DPK -> Kredit & 0,195 & 0,096 & $0,044^{* *}$ & 2,02 & Diterima \\
Hipotesis 3 & NIM -> DPK & 0,32 & 0,07 & $0,000^{*}$ & 4,559 & Diterima \\
\hline
\end{tabular}

Catatan: ${ }^{*} p<1 \%$; ${ }^{* *} p<5 \%$ (Sumber : Data diolah, 2019) 
Tabel 4

Uji Mediasi (Indirect Effects)

\begin{tabular}{llcccccc}
\hline Hipotesis & Variabel & $\begin{array}{c}\text { Original } \\
\text { Sample }\end{array}$ & $\begin{array}{c}\text { Sample } \\
\text { Mean }\end{array}$ & $\begin{array}{c}\text { Standar } \\
\text { Deviasi }\end{array}$ & $\begin{array}{c}\text { T } \\
\text { Statistics }\end{array}$ & P Value & Ket \\
\hline Hipotesis 4 & $\begin{array}{l}\text { NIM -> DPK- } \\
\text { > Kredit }\end{array}$ & 0,062 & 0,065 & 0,035 & 1,784 & $0,075^{\star * *}$ & $\begin{array}{c}\text { Diterima } \\
\text { (Mediasi } \\
\text { Parsial) }\end{array}$ \\
\hline
\end{tabular}

Catatan :* $p<1 \% ;{ }^{* *} p<5 \% ;{ }^{* * *} p<10 \%$ (Sumber : data diolah, 2019)

Tabel 4 menjelaskan pengaruh mediasi variabelDPK terhadap NIM dan pertumbuhan kredit. Diperoleh hasil bahwa dampak NIM terhadap kredit bank adalah signifikan positif (sig 0,075 dan koefisien NIM 0,062). Dengan demikian, hasil menunjukkan bahwa peran mediasi DPK adalah signifikan positif terhadap NIM dan pertumbuhan kredit. Pengaruh tidak langsung NIM terhadap pertumbuhan kredit terjadi secara parsial (mediasi parsial) karena NIM secara langsung juga signifikan terhadap pertumbuhan kredit. Dengan demikian, Hipotesis penelitian diterima. Variabel DPK dapat memediasi secara signifikan positif hubungan antara NIM terhadap pertumbuhan kredit. Besarnya DPK mendorong NIM bank mempengaruhi pertumbuhan kredit bank. Hasil penelitian mendukung hasil penelitian terdahulu (Pratiwi \& Hindasah, 2014; Risal Rinofah, Ayu Laksita Widaresti, 2018; Sri Hermuningsih, 2011).

\begin{tabular}{cc}
\multicolumn{2}{c}{ Tabel $\mathbf{5}$} \\
\multicolumn{2}{c}{ R Square } \\
\hline DPK & 0,092 \\
Kredit & 0,051 \\
\hline Sumber; Data diolah, 2019
\end{tabular}

Tabel 5 menjelaskan bahwa nilai $R$ square DPK adalah 0,092 dan pertumbuhan kredit 0,051 . Tabel $R$ square menjelaskan bahwa variabel berpengaruh terhadap variabel dependen kredit sebesar 0,051 atau 5,1\% dan $94,9 \%$ dipengaruhi variabel lain diluar model. Variabel dependen DPK dipengaruhi variabel independen sebesar 0,092 atau $9,2 \%$ dan $90,8 \%$ dipengaruhi variabel lain diluar model.

Tabel 6

F Square

\begin{tabular}{lll}
\hline Variabel & DPK & Kredit \\
\hline DPK & - & 0,037 \\
Kredit & - & - \\
NIM & 0,114 & 0,018 \\
\hline \multicolumn{2}{c}{ Sumber : data diolah, 2019 }
\end{tabular}

Tabel 6 menjelaskan bahwa nilai $F$ square DPK terhadap kredit adalah 0,037, NIM terhadap DPK 0,114 dan NIM terhadap pertumbuhan kredit 0,018 .

\section{Kesimpulan}

Penelitian ini menjawab pertanyaan dari permasalahan penelitian adalah sebagai berikut:

1. Besarnya NIM dapat mendorong pertumbuhan DPK sehingga berdampak pada pertumbuhan kredit bank.

2. Variabel DPK dapat memediasi signifikan positif pengaruh NIM terhadap pertumbuhan kredit.

\section{Keterbatasan penelitian}

Keterbatasan penelitian adalah jumlah variabel yang digunakan untuk menguji pengaruh pertumbuhan kredit masih sedikit sehingga perlu pengembangan variabel lain diluar model penelitian ini.

\section{Saran}

\section{Bagi Manajemen Bank}

1. Manajemen bank sebaiknya mengontrol besarnya net interest margin bank untuk meningkatkan jumlah Dana pihak ketiga (DPK) dan pertumbuhan kredit.

2. Manajemen bank sebaiknya menjaga 
pertumbuhan dana pihak ketiga (DPK) untuk meningkatkan pertumbuhan kredit.

\section{Bagi Penelitian Selanjutnya}

Peneliti selanjutnya dapat menambah variabel lain diluar model sehingga literatur tentang determinan pertumbuhan kredit bank dapat diketahui lebih banyak, misalnya faktor kepemilikan bank.

\section{DAFTAR PUSTAKA}

Aini Nihayati, Sugeng Wahyudi, M. S. (2014). Pengaruh Ukuran Bank, BOPO, Risiko Kredit, Kinerja Kredit Dan Kekuatan Pasar Terhadap Net Interest Margin (Studi Perbandingan pada Bank Persero dan Bank Asing Periode Tahun 2008-2012). Jurnal Bisnis Strategi, 23(2), 14-44.

Bank of Indonesia. (2017). Kajian Stabilitas Keuangan. Mitigasi Risiko Sistemik Melalui Penguatan Koordinasi Antar Institusi Di Tengah Konsolidasi Perekonomian Domestik, 28(Maret), 1-5. https://doi.org/10.1007/s13398-014-0173-7.2

Marinkovic, S., \& Radovic, O. (2010). On the determinants of interest margin in transition banking: the case of Serbia. Managerial Finance, 36(12), 1028-1042. https://doi. org/10.1108/03074351011088432

Pratiwi, S., \& Hindasah, L. (2014). Pengaruh Dana Pihak Ketiga, Capital Adequacy Ratio, Return Nn Asset, Net Interest Margin Dan Non Performing Loan Terhadap Penyaluran Kredit Bank Umum Di Indonesia. Jurnal Manajemen Bisnis, 5(2), 192-208.

Ratu Mashita Gumilarty, G., \& Indriani, A. (2017). Analisis Pengaruh DPK, NPF, ROA, Penempatan Dana Pada SBIS, Dan Tingkat Bagi Hasil Terhadap Pembiayaan Bagi Hasil (Vol. 5).

Rinofah, R. (2018). Pengaruh Variabel Ekonomi Makro Terhadap Penyaluran Kredit Umum Dan Umkm Di Daerah Istimewa Yogyakarta. SOSIOHUMANIORA: Jurnal IImiah IImu Sosial Dan Humaniora, 1(1). https://doi.org/10.30738/sosio.v1i1.515

Risal Rinofah, Ayu Laksita Widaresti, No. D. P. (2018). Determinan Risk Taking Bank Perkreditan Rakyat di Daerah Istimewa Yogyakarta. Jurnal AKuntansi Dan Manajemen Akmenika, 15(1), 26-37.

Romli, H., \& Alie, M. (2017). Diterminan Penyaluran Kredit dan Implikasinya Terhadap Kinerja Profitabilitas Bank yang Terdaftar di Bursa Efek Indonesia Periode 2010-2014. Jurnal Manajemen Dan Bisnis Sriwijaya, 15(1).

Sri Hermuningsih, D. K. W. (2011). Faktor-Faktor yang Mempengaruhi Kinerja Bank Dengan Skim Bunga Kredit Sebagai variabel Intervening. Proceeding Call For Paper Dan Smeinar Nasional, 11(1), 57-64.

Trinugroho, I., Agusman, A., \& Tarazi, A. (2014). Why have bank interest margins been so high in Indonesia since the 1997/1998 financial crisis? Research in International Business and Finance, 32, 139-158. https://doi.org/10.1016/j.ribaf.2014.04.001

Trinugroho, I., Risfandy, T., \& Ariefianto, M. D. (2018). Competition, diversification, and bank margins: Evidence from Indonesian Islamic rural banks. Borsa Istanbul Review, 18(4), 349-358. https://doi.org/10.1016/j.bir.2018.07.006 